This article was published in Chemosphere, 139, 276-287, 2015

http://dx.doi.org/ 10.1016/i.chemosphere.2015.06.078

\title{
Scented Traces - Dermal exposure of synthetic musk fragrances in personal care products and environmental input assessment
}

Vera Homem*, Eduardo Silva, Arminda Alves, Lúcia Santos

LEPABE - Laboratory for Process Engineering, Environment, Biotechnology and Energy, Faculty of Engineering, University of Porto, Rua Dr. Roberto Frias, 4200-465, Porto, Portugal

*Corresponding author. Tel.: +351 22041 4947, Fax: +351 22508 1449, e-mail address: vhomem@fe.up.pt

\section{E-mail addresses}

Vera Homem: vhomem@fe.up.pt

Eduardo Silva: 9.eduardosilva@gmail.com

Arminda Alves: aalves@fe.up.pt

Lúcia Santos: 1santos@fe.up.pt 


\begin{abstract}
Synthetic musks are organic compounds used as fragrance and fixative additives in several personal care products. Until now, little is known about their occurrence and distribution in these household commodities. However, this information is essential to perform a human dermal exposure assessment. Therefore, this study gives an overview on the levels of 12 synthetic musks in 140 personal care products from 7 different categories (body and hair wash, toilet soaps, shaving products, dentifrice products, deodorants/antiperspirants, moisturizers and perfumes). They were analysed by QuEChERS extraction followed by gas chromatography-mass spectrometry. Detection limits were found between $0.01 \mathrm{ng} \mathrm{g}^{-1}$ (galaxolide) and $5.00 \mathrm{ng} \mathrm{g}^{-1}$ (musk xylene). Higher average concentrations of total synthetic musks were detected in perfumes (5245.05 $\left.\mu \mathrm{g} \mathrm{g}^{-1}\right)$ and shampoos $\left(487.67 \mu \mathrm{g} \mathrm{g}^{-1}\right)$ for adults. Galaxolide, exaltolide and cashmeran were the most detected compounds. Combining these results with the daily usage amounts, an average daily dermal exposure of $75.69 \mu \mathrm{g} \mathrm{kg} \mathrm{bw}^{-1} \mathrm{day}^{-1}$ for adults and $15.54 \mu \mathrm{g} \mathrm{kg} \mathrm{bw}^{-1} \mathrm{day}^{-1}$ for babies/children was achieved. An average daily dermal exposure to synthetic musks of $75.69 \mu \mathrm{g}$ $\mathrm{kg}_{\mathrm{bw}}{ }^{-1} \mathrm{day}^{-1}$ for adults and $15.54 \mu \mathrm{g} \mathrm{kg} \mathrm{bw}^{-1} \mathrm{day}^{-1}$ for babies/children were achieved. The main contributors for adult and babies/children dermal exposure were perfumes and lotions, respectively. About $40 \%$ of the adult daily dermal exposure is related to exaltolide, $30 \%$ galaxolide, and $15 \%$ tonalide, while for babies/children $96 \%$ occurs due to exaltolide.

An estimate of the amount of musks discharged "down-the-drain" into the wastewater treatment systems through the use of toiletries was also performed. An average emission per capita of $6.7 \mathrm{mg} \mathrm{day}^{-1}$ was determined and galaxolide and exaltolide were the predominant musks in the effluents.
\end{abstract}

Keywords: Synthetic musks; Personal care products; Human and environmental exposure 


\section{Abbreviations}

A, amount of product applied per application; ADBI, celestolide; AHMI, phantolide; AHTN, tonalide; AMs, alicyclic musks; BW, average body weight; $\mathrm{C}$, musk concentration in the toiletry product; $D_{\text {exp }}$, daily dermal exposure per capita; $D_{\text {upt, }}$ daily dermal uptake per capita; DPMI, cashmeran; EB, ethylene brassylate; EI, electron ionization; Em, estimated "down-the-drain" emission per capita; EXA, exaltolide; $F$, frequency of application; $F_{\text {dermal, }}$ permeation factor; $\mathrm{F}_{\text {evap}}$, evaporation factor; GC-MS, gas chromatography-mass spectrometry; HHCB, galaxolide; i, type of toiletry product; $\mathrm{j}$, type of synthetic musk; m, number of synthetic musks; MA, musk ambrette; MK, musk ketone; MM, musk moskene; MMs, macrocyclic musks; MT, musk tibetene; MX, musk xylene; n, number of toiletry products; NMs, nitromusks; PCPs, personal care products; PMs, polycyclic musks; QuEChERS, Quick, Easy, Cheap, Rugged and Safe; R, retention factor; SIS, selected ion storage; 


\section{Introduction}

Synthetic musks are used as fragrance additives and fixative compounds in several toiletries, personal care and household products (Lu et al., 2011). According to their chemical structure, these compounds can be divided into four main classes: nitro- (NMs), polycyclic (PMs), macrocyclic (MMs) and alicyclic (AMs) musks (Homem et al., 2015; Arbulu et al., 2011). NMs were first produced commercially in 1900s as substitutes for the natural musks (Lee et al., 2010; Schmeiser et al., 2001). For many years, this class dominated the market, but its use significantly declined in the 90s due to its toxicity, bioaccumulation and molecular instability (Bester, 2009; Taylor et al., 2014). In fact, European Union has established maximum authorized concentrations for some of these compounds in cosmetic products: $0.042-1.4 \%$ and $0.03-1.0 \%$ for musks ketone and xylene, respectively, depending on the cosmetic product (none of them can be used in oral products), while musks ambrette, tibetene and moskene were prohibited (European Parliament, 2009). PMs slowly supplanted the NMs through their low production cost and high resistance to light and alkali (Roosens et al., 2007). They have been widely used, but their detection in environmental and even human matrices as blood (Hutter et al., 2010; Hutter et al., 2005, 2009), breast milk (Kang et al., 2010; Wang et al., 2011; Yin et al., 2012; Zhang et al., 2011; Zhou et al., 2012) and umbilical cord serum (Kang et al., 2010) aroused concerns in the scientific community, instigating a decrease in the production levels. The other two groups of synthetic musks (MMs, AMs) have been recently introduced in the market. The MMs are chemically similar to the natural musk odorants and consequently, they seem to be more easily degradable in the environment (Bester, 2009). In the near future, it is expected that the decrease in the synthesis' price of these musks coupled to their environmentally friendly properties, will favour the replacement of the PMs by the MMs. AMs are the $4^{\text {th }}$ generation of odorant musks, but their use in personal care products (PCPs) is still very scarce.

The massive, widespread and continuous use of synthetic musks and their lipophilic nature make these compounds interesting for further research including studies on characterization and risk assessment. As mentioned above, PCPs constitute the main source of environmental contamination, but also the primary route for human exposure (Reiner and Kannan, 2006; 
Roosens et al., 2007). Although, cosmetic labelling requirements state that all PCPs produced or distributed for retail sale to consumers bear a list of ingredients, ordered by prevalence (descending order of weight), ingredients used in fragrances are considered trade secrets and are exempt from these labelling requirements (European Parliament, 2009). Typically, fragrances created for cosmetic purposes are dominated by synthetic ingredients, such as musks (Llompart et al., 2013). The term "parfum" or "aroma" are usually used to represent this complex mixture of scented chemicals. In order to assure product safety according to regulations and to assess the health risk from the potential exposures, the determination of concentration profiles of synthetic musks in PCPs formulations is mandatory. Although several studies have been conducted to determine synthetic musks in environmental and human body compartments, few have focused on the determination of these compounds in PCPs. In fact, most studies present the development of new analytical methodologies to determine synthetic musks in PCPs (Dong et al., 2014; Correia et al., 2013; Homem et al., 2013; Llompart et al., 2013; Sanchez-Prado et al., 2011), but very few have assessed human exposure to these compounds, analysing a large sample pool (more than 100 samples from different categories of products) (Lu et al., 2011).

For instance, Reiner and Kannan (2006) analysed galaxolide (HHCB), tonalide (AHTN) and HHCB-lactone in 60 toiletries and household commodities in the USA. They found that concentrations of HHCB, AHTN and HHCB-lactone ranged from $<5 \mathrm{ng} \mathrm{g}^{-1}$ to $5 \mathrm{mg} \mathrm{g}^{-1},<5 \mathrm{ng} \mathrm{g}^{-}$ ${ }^{1}$ to $0.5 \mathrm{mg} \mathrm{g}^{-1}$ and $<5 \mathrm{ng} \mathrm{g}^{-1}$ to $0.2 \mathrm{mg} \mathrm{g}^{-1}$, respectively, and the highest concentrations were detected in perfume and body lotion/cream samples. Roosens et al. (2007) determined two polycyclic (HHCB and AHTN) and two nitromusks (musk ketone, MK; musk xylene, MX) in 82 PCPs from Belgium. High amounts of synthetic musks were determined in body lotions, perfumes and deodorants. HHCB and AHTN showed high detection frequencies and concentrations, reaching the 22 and $8 \mathrm{mg} \mathrm{g}^{-1}$, respectively. They also estimated the exposure profiles to these compounds, concluding that a maximum value of $35 \mathrm{mg} \mathrm{g}^{-1}$ is expected. Similar trends were observed in commercial products from China (Lu et al., 2011; Zhang et al., 2008) and also Spain (Llompart et al., 2013; Sanchez-Prado et al., 2011). However, Lu et al. (2011) determined a lower adult dermal exposure to musks $\left(3.38 \mathrm{mg} \mathrm{day}^{-1}\right)$ based on their median concentrations and the 
average daily usage amounts of consumer products. Correia et al. (2013) studied the occurrence of $\mathrm{HHCB}$ in 7 personal care products from Portugal and verified that perfumed body cream contained the highest concentration of this compound. With the information regarding these toiletries, the authors estimated a total daily dermal exposure to HHCB of $904 \mu \mathrm{g} \mathrm{day}^{-1}$ (equivalent to $15 \mu \mathrm{g} \mathrm{kg} \mathrm{bw}^{-1}$ day $\left.^{-1}\right)$. Nakata et al. (2015) reported the occurrence and concentrations of macrocyclic-, polycyclic- and nitromusks in cosmetics and household commodities from Japan. Similarly, they found that HHCB were the predominant musk, also presenting higher concentration levels (up to $15 \mathrm{mg} \mathrm{g}^{-1}$ in perfumes). Higher concentrations and detection frequencies were also verified for the macrocyclic musks musk T, habanolide and exaltolide (up to $\left.11 \mathrm{mg} \mathrm{g}^{-1}\right)$. The estimated daily intakes of musk T and HHCB by dermal exposure to personal care products were around $8 \mu \mathrm{g} \mathrm{kg} \mathrm{bw}{ }^{-1}$ day $^{-1}$, while for habanolide, exaltolide and AHTN the values were between 1 and $5 \mu \mathrm{g} \mathrm{kg} \mathrm{bw}^{-1}$ day $^{-1}$.

As can be seen, studies concerning different geographical areas (USA, Europe, China or Japan) led to distinct results. In fact, this reflects the dependency between the use pattern of synthetic musks in PCPs and the different regions of the world. This use pattern is related, not only to the different regulations in force in each country, but also with the use daily rates of the products, which are linked to the habits of the population. In fact, this information on the occurrence and concentrations of synthetic musks in PCPs and also human exposure through dermal absorption are very limited. Therefore, the aim of this study was to analyse the concentration profiles of synthetic musks in a large number of PCPs purchased in retail stores in Portugal, enabling the assessment of human exposure (adults and baby/children) through their use. It is also expected to estimate "down-the-drain" emissions based on this qualitative/quantitative evaluation of consumer use of musks containing PCPs.

\section{Material and methods}

\subsection{Chemicals and materials}

The synthetic polycyclic musks cashmeran (DPMI), celestolide (ADBI), galaxolide (HHCB), phantolide (AHMI) and tonalide (AHTN) were obtained from LGC Standards (Barcelona, Spain) 
as solid standards with $99 \%$ purity, except for $\mathrm{HHCB}$ which contains approximately $25 \%$ of diethyl phthalate. Musk tibetene (MT) and musk moskene (MM) were also purchased from LGC Standards, but as $10 \mathrm{mg} \mathrm{L}^{-1}$ solution in cyclohexane. Musk ambrette (MA) and musk ketone (MK) were purchased as solid standards from Dr. Ehrenstorfer GmbH (Augsburg, Germany) with 99\% and $98 \%$ purity, respectively. Musk xylene (MX) was purchased as $100 \mathrm{mg} \mathrm{L}^{-1}$ solution in acetonitrile, exaltolide (EXA) as a solid standard with $\geq 95 \%$ purity and ethylene brassylate (EB) with $\geq 99 \%$ purity to Sigma-Aldrich (St. Louis, MO, USA). Stock solutions of each analyte ( $10 \mathrm{~g}$ $\mathrm{L}^{-1}$ ) were prepared in cyclohexane and the final mixed stock solution was prepared in acetonitrile. All solutions were preserved at $-20{ }^{\circ} \mathrm{C}$ and protected from the light. The chemical structures of the synthetic musks analysed in this study are shown in Fig. 1.

Anhydrous magnesium sulphate and sodium acetate were obtained from Sigma-Aldrich (St. Louis, MO, USA), while PSA bonded silica and $\mathrm{C}_{18}$ from Supelco (Bellefonte, PA, USA). The $\mathrm{MgSO}_{4}$ was baked at $450{ }^{\circ} \mathrm{C}$ overnight before use. All organic solvents (analytical grade) were purchased from VWR (Fontenay-sous-Bois, France).

\subsection{Samples}

A total of 140 personal care products were purchased from retail stores in Porto, Portugal, in 2012. The samples were divided into different categories according to their overall composition: body and hair wash $(n=47)$, toilet soaps $(n=15)$, shaving products $(n=12)$, dentifrice products $(n=12)$, deodorants/antiperspirants $(n=12)$, moisturizers $(n=22)$ and perfumes $(n=20)$. Samples were kept in their original containers at room temperature until analysis.

\subsection{Extraction procedure}

Details of the extraction have been described elsewhere (Homem et al., 2013). Briefly, $3 \mathrm{~mL}$ of acetonitrile was added to $500 \mathrm{mg}$ of each sample and the mixture were vortexed and sonicated during $3 \mathrm{~min}$ and $10 \mathrm{~min}$, respectively. After this, a QuEChERS containing $2400 \mathrm{mg}$ anhydrous $\mathrm{MgSO}_{4}$ and $750 \mathrm{mg} \mathrm{NaCH} \mathrm{COO}_{3}$ was added and the mixture was vortexed (3 min) and centrifuged for $10 \mathrm{~min}$ at $3700 \mathrm{rpm}$. The supernatant was removed and added to a second QuEChERS (180 
mg magnesium sulphate, $60 \mathrm{mg}$ PSA, $30 \mathrm{mg} \mathrm{C}_{18}$ ) and the mixture was vortexed and centrifuged again. The collected supernatant was concentrated to $1 \mathrm{~mL}$ under a gentle stream of nitrogen before being analysed by GC-MS. Whenever necessary, extracts were further diluted to an appropriate volume and reanalysed. Perfume samples were simply diluted in acetonitrile and analysed by GC-MS.

\subsection{GC-MS analysis}

Chromatographic analysis of synthetic musk compounds were done in a Varian Ion Trap GCMS system (Walnut Creek, CA, USA), equipped with a 450-GC gas chromatograph, a 240-MS ion trap mass spectrometer operating in the electron ionization (EI) mode $(70 \mathrm{eV})$, a CP-1177 split/splitless injector and an autosampler model CP-8410. After a $1 \mu \mathrm{L}$ injection in splitless mode, separation was achieved using a Varian CP-Sil 8 CB capillary column $(50 \mathrm{~m} \times 0.25 \mathrm{~mm}$ i.d., $0.12 \mu \mathrm{m})$ in combination with a FS deactivated pre-column $(5 \mathrm{~m} \times 0.530 \mathrm{~mm}$ i.d. $)$ from Agilent Technologies (Palo Alto, CA, USA). The oven temperature was programmed as follows: $60{ }^{\circ} \mathrm{C}$ hold for $1 \mathrm{~min}$, raised at $6{ }^{\circ} \mathrm{C} \mathrm{min}-1$ to $150{ }^{\circ} \mathrm{C}$ (hold for $10 \mathrm{~min}$ ), then $6{ }^{\circ} \mathrm{C} \min ^{-1}$ to $225{ }^{\circ} \mathrm{C}$ and finally $20^{\circ} \mathrm{C} \mathrm{min}-1$ to $300{ }^{\circ} \mathrm{C}$ (hold for $2.5 \mathrm{~min}$ ). The filament emission current was $50 \mu \mathrm{A}$, the manifold was maintained at $50{ }^{\circ} \mathrm{C}$, while the injector, ion trap and transfer line were at 250 ${ }^{\circ} \mathrm{C}$. Helium (99.999\% purity) was used as carrier gas at $1.0 \mathrm{~mL} \mathrm{~min}{ }^{-1}$. Acquisition was made in selected ion storage (SIS) mode and synthetic musks were identified and quantified using retention time and up to three ions with the Varian MS workstation v. 6.9.3 software. The ions monitored for individual compounds have been previously reported (Homem et al., 2013).

\subsection{Method validation}

Linear behaviour between 5 and $4000 \mu \mathrm{g} \mathrm{L}^{-1}$ was obtained for all synthetic musks, except for EXA, EB, MA (25 - $\left.4000 \mu \mathrm{g} \mathrm{L}^{-1}\right)$ and MX $\left(10-4000 \mu \mathrm{g} \mathrm{L} \mathrm{L}^{-1}\right)$. Limits of detection (LODs) were calculated by the signal-to-noise ratio of 3 and were $0.01 \mathrm{ng} \mathrm{g}^{-1}$ for HHCB, $0.17 \mathrm{ng} \mathrm{g}^{-1}$ for AHMI, $0.34 \mathrm{ng} \mathrm{g}^{-1}$ for ADBI, $0.49 \mathrm{ng} \mathrm{g}^{-1}$ for DPMI, $1.94 \mathrm{ng} \mathrm{g}^{-1}$ for MK, $2.22 \mathrm{ng} \mathrm{g}^{-1}$ for AHTN, $2.86 \mathrm{ng}$

$\mathrm{g}^{-1}$ for MM, $3.33 \mathrm{ng} \mathrm{g}^{-1}$ for EXA, $3.75 \mathrm{ng} \mathrm{g}^{-1}$ for MA and $5.00 \mathrm{ng} \mathrm{g}^{-1}$ for MX and EB. Accuracy 
was evaluated by recovery tests at three levels $\left(200,400\right.$ and $\left.800 \mathrm{ng} \mathrm{g}^{-1}\right)$ and different values were obtained according to the type of formulation studied: body and hair wash - 56 (ADBI) to $112 \%$ (MX), toilet soaps - 58 (AHMI) to 106\% (HHCB), shaving products - 95 (MA) to 102\% (MT), dentifrice products - 50 (HHCB, MM) to $107 \%$ (DPMI), deodorants - 89 (MX, MM, DPMI) to 104\% (MT), moisturizers - 82 (DPMI) to 109\% (MX, MK) and perfumes - 98 (DPMI) to 102\% (MX).

The applied extraction methodology did not yield acceptable results for EB. In fact, the mass spectra of this compound resemble very much with those of natural fatty acids or their derivatives present in most analysed samples. Therefore, EB was only analysed in perfume samples (\%Rec $=99 \%)$. The relative standard deviation at all spiked levels for all type of samples was below $15 \%$.

\subsection{Quality assurance/quality control}

Due to the widespread use of synthetic musks, special precautions were taken in order to prevent samples contamination. During this study, analysts avoided the use of personal care products containing fragrance compounds and switched gloves whenever they changed sample. Procedural blanks were analyzed with every extraction batch. Trace levels of HHCB, AHTN and EXA were detected in these procedural blanks. Blank values were subtracted for all of the concentrations reported. Chromatographic blanks were also performed, but no memory effects were observed.

\subsection{Estimation of dermal exposure}

To estimate the daily dermal exposure and uptake the following parameters were taking into account: product type (e.g. leave-on, rinse-off), amount per application, frequency and target group of use (baby and children, adults).

To give a general overview, two scenarios were drawn, using the average and highest concentration values (worst-case scenario) for each musk compound in all categories. The daily exposure per capita was evaluated according to the Eq.1 (Nakata et al., 2015): 


$$
D_{\exp }=\sum_{i=1}^{n} \sum_{j=1}^{m} \frac{C_{j} \times A_{i} \times F_{i} \times R_{i}}{B W}
$$

where $D_{\text {exp }}$ : daily dermal exposure per capita $\left(\mathrm{mg} \mathrm{kg} \mathrm{bw}^{-1}\right.$ day $\left.^{-1}\right), i$ : type of toiletry product, $n$ : number of PCPs, $j$ : type of synthetic musk (e.g. HHCB, AHTN, etc), $m$ : number of synthetic musks, $C$ : musk concentration in the toiletry product $\left(\mathrm{mg} \mathrm{kg}^{-1}\right), A$ : amount of product applied per application $\left(\mathrm{kg}\right.$ event $\left.^{-1}\right), F$ : frequency of application $\left(\right.$ events day $\left.{ }^{-1}\right), R$ : retention factor (dimensionless), $B W$ : average body weight $(\mathrm{kg})$.

The retention factor represents the product amount that may be retained on the skin and/or the likelihood of the musk ingredient being removed by washing. Therefore, it varies between 0.0 and 1.0, in which 0.0 indicates that the entire product is rinsed-off and 1.0 that none of the product is rinsed-off.

A daily dermal uptake per capita $\left(D_{u p t}\right)$ was also evaluated (Eq. 2) through the inclusion of a permeation factor $\left(F_{\text {dermal }}\right)$. Factors of 1.0 indicate that the target compound will be totally permeated through the skin.

$$
D_{\text {int }}=D_{\text {exp }} \times F_{\text {dermal }}
$$

\section{Results and Discussion}

\subsection{Synthetic musks in personal care products}

In order to estimate the use pattern of personal care products by the population of the Oporto region, the best selling brands of these products were selected.

Synthetic musks were detected in all analysed samples and their concentrations varied between $0.01 \mathrm{ng} \mathrm{g}^{-1}$ and $30 \mathrm{mg} \mathrm{g}^{-1}$ (Table 1 and Tables $\mathbf{S 1}$ to $\mathbf{S} 7$ from the Supporting Information). In fact, in most cases more than one compound was identified in the constitution of the same sample (average of 3 musks per sample). HHCB (92\%), EXA (73\%) and DPMI (60\%) were the most frequently detected musks. The remaining studied compounds were detected in less significant percentages $(<25 \%)$. 
Polycyclic musks were the most detected class (96\%). As expected, considering all products $\left(\mathrm{n}=140\right.$ ), higher concentration levels were found for AHTN (average: $2306.21 \mu \mathrm{g} \mathrm{g}^{-1}$, maximum: 19840.21 $\mu \mathrm{g} \mathrm{g}^{-1}$ ) and HHCB (average: $1677.82 \mu \mathrm{g} \mathrm{g}^{-1}$, maximum: $31124.00 \mu \mathrm{g} \mathrm{g}^{-1}$ ). These results are in agreement with the production data of polycyclic musks in Europe (Salvito, 2005). Similar studies also refer that these two compounds are usually more often detected and in higher concentrations. For instance, Lu et al. (2011) studied 158 personal care products from China and found synthetic musks in $82 \%$ of the analysed samples. The most frequently detected musks were HHCB (73\%) and AHTN (65\%) and they were also detected in higher concentration levels (HHCB - average: $52.3 \mu \mathrm{g} \mathrm{g}^{-1}$, maximum: $1010 \mu \mathrm{g} \mathrm{g} \mathrm{g}^{-1}$ and AHTN - average: $12.4 \mu \mathrm{g} \mathrm{g}^{-1}$, maximum: $225 \mu \mathrm{g} \mathrm{g}^{-1}$ ). A similar situation was verified by Reiner and Kannan (2006) and Zhang et al. (2008). The first authors detected HHCB in $72 \%$ of the 60 samples analysed (USA), with average concentrations up to $1280 \mu \mathrm{g} \mathrm{g}^{-1}$ and AHTN in $32 \%$ with concentration levels up to 155 $\mu \mathrm{g} \mathrm{g}^{-1}$. Zhang et al. (2008) investigated 31 samples from the Chinese market, and detected HHCB in $61 \%$ of the total samples analysed (highest mean concentration of $804 \mu \mathrm{g} \mathrm{g}^{-1}$ ) and AHTN in 36\% (47 $\left.\mu \mathrm{g} \mathrm{g}^{-1}\right)$. Llompart et al. (2013) studied 26 personal care products from Spain and also detected both HHCB $\left(0.0358-3640 \mu \mathrm{g} \mathrm{g}^{-1}\right)$ and AHTN $\left(0.0115-1960 \mu \mathrm{g} \mathrm{g}^{-1}\right)$ in most samples (65\%). Nakata et al. (2015) reported the occurrence and concentrations of different synthetic musks in 73 cosmetics collected from Japan. The high concentrations and detection frequencies were found for the same compounds (HHCB: nd - $15000 \mu \mathrm{g} \mathrm{g}^{-1}$, AHTN: nd - $1900 \mu \mathrm{g} \mathrm{g}^{-1}$ ). Roosens et al. (2007) verified an opposite trend in the analysis of 82 personal care products from Belgium. They verified that AHTN was present in $70 \%$ of the samples, with concentration levels up to $8000 \mu \mathrm{g} \mathrm{g}^{-1}$ and $\mathrm{HHCB}$ only in $55 \%$, with concentration levels up to $22000 \mu \mathrm{g} \mathrm{g}^{-1}$.

Concentration levels found in this study for HHCB and AHTN were similar to those reported by European and Japanese studies (Llompart et al., 2013; Roosens et al., 2007; Reiner and Kannan, 2006; Nakata et al., 2015) and one to two orders of magnitude higher than those described in China (Lu et al., 2011; Zhang et al., 2008). In fact, the consumption patterns and legislation vary geographically, which may explain these variations. This kind of musks were 
found in almost all categories of products, namely in perfumes, moisturizers and body and hair wash.

The nitromusks MA, MM and MT, whose use was banned in the European Union (European Parliament, 2009) were not detected in any of the samples. However, the restricted nitromusks MX and MK were identified in 1\% (shampoo) and 6\% (hand cream, gel soap, shampoo and hair conditioner) of the analysed samples, respectively. They were detected at low concentrations (mean values of $8.59 \mu \mathrm{g} \mathrm{g}^{-1}$ for MK and $3.42 \mu \mathrm{g} \mathrm{g}^{-1}$ for MX), meeting the legal limits (Table 1). The lower concentrations and detection frequencies of MK and MX were consistent with previous studies, which usually mentioned detection frequencies below 10\% (Roosens et al., 2007; Zhang et al., 2008; Llompart et al., 2013; Nakata et al., 2015) and concentrations below $10 \mu \mathrm{g} \mathrm{g}^{-1}$ as Roosens et al. (2007), Zhang et al. (2008) or Llompart et al. (2013). This demonstrates that nitromusks production in Europe and, subsequent incorporation into toiletries has been dramatically reduced over the past few years (Llompart et al., 2013).

The two macrocyclic musks under study, EB and EXA, have been detected in about $76 \%$ of the samples. As mentioned before, the first has been studied only in perfume samples, due to matrix effect problems in other samples. EB was detected in about $58 \%$ of perfume samples analysed and its concentration varied between 2.4 and $24485.94 \mu \mathrm{g} \mathrm{g}^{-1}$ (Table 1). The EXA was detected in all categories of products, with the exception of dentifrice products. The frequency of detection was higher in shaving products $(100 \%)$, moisturizers $(82 \%)$ and body and hair wash (81\%). Similarly to polycyclic musks, EXA was detected at a higher concentration in perfume samples (up to $22000 \mu \mathrm{g} \mathrm{g}^{-1}$ ). To the authors' best knowledge, these two macrocyclic musks were only analysed once before in personal care products from Japan (Nakata et al., 2015). The similar behaviour was observed by these authors. In fact, EB and EXA were dominant in several personal care products, with higher incidence in perfumes (69\% and concentrations up to $11000 \mu \mathrm{g} \mathrm{g}^{-1}$ for EB and $38 \%$ and $6700 \mu \mathrm{g} \mathrm{g}^{-1}$ for EXA) and body soaps (100\% and concentrations up to $600 \mu \mathrm{g}$ $\mathrm{g}^{-1}$ for EB and $60 \%$ and $88 \mu \mathrm{g} \mathrm{g}^{-1}$ for EXA). 
The obtained data confirmed the trend of replacing the nitromusks by polycyclic musks with a comprehensible prevalence of HHCB and AHTN. It was also worth noting the introducing of macrocyclic musks (compounds with similar structures to natural musks), such as EXA and EB.

Higher average concentrations of total synthetic musks were found in perfumes $(5245.05 \mu \mathrm{g}$ $\left.\mathrm{g}^{-1}\right)$, shampoos $\left(487.67 \mu \mathrm{g} \mathrm{g}^{-1}\right)$, body moisturizers $\left(154.13 \mu \mathrm{g} \mathrm{g}^{-1}\right)$ and hair conditioners $(66.43 \mu \mathrm{g}$ $\mathrm{g}^{-1}$ ) for adults (Table 1). As expected, the lowest concentrations were detected in toothpastes $\left(0.02 \mu \mathrm{g} \mathrm{g}^{-1}\right)$. Similar results were found by Roosens et al. (2007), Reiner and Kannan (2006) and Zhang et al. (2008), who concluded that perfumes and moisturizers were the products with the highest levels of musks. Conversely, toothpastes revealed the lowest levels.

Personal care products for babies and children presented lower levels than products for adults, with the exception of children toothpastes. Comparing the concentration HHCB in adults and children toothpaste, a mean amount of $0.002 \mu \mathrm{g} \mathrm{g}^{-1}$ (adults) and $0.01 \mu \mathrm{g} \mathrm{g}^{-1}$ (children) were found. In fact, children's toothpastes are made to taste good, so this higher concentration may be related to the flavour improvement of the product. To the authors' best knowledge, only one study provides the concentration levels of synthetic musks in personal care products for babies/children (Dong et al., 2014), which hinders a deep discussion of the results. However, in that study, the authors analysed 24 adult and 4 baby creams and concluded that lower levels were found in the latter matrices $\left(<0.01 \mu \mathrm{g} \mathrm{g}^{-1}\right)$, which is in accordance with the present study.

The composition of the different classes of personal care products (adult and baby/children) was also examined (Fig. 2). HHCB and EXA were the predominant musks, representing more than $50 \%$ of the composition of each category of the products analysed. HHCB is most used in the manufacture of hair conditioners $(91 \%)$, shampoos and solid soaps $(88 \%)$, while EXA is employed deodorants (93\%) and body moisturizers (84\%).

\subsection{Exposure assessment by dermal application}

The main exposure route for synthetic musks is through dermal absorption since they are present in PCPs that are usually applied directly onto the skin (Cadby et al., 2002; Lu et al., 2011). As previously mentioned, in contrast to the common practice of choosing the products for a product survey at random, for this study the best selling brands of PCPs in the Oporto region were 
selected. Using this procedure, we were able to focus the experimental efforts on the products that contribute most to consumer exposure.

In the present work, dermal exposure $\left(D_{\text {exp }}\right)$ and uptake $\left(D_{\text {upt }}\right)$ were determined for two age groups of consumers, adults and children (Table 2 and 3). For the first group, exposure amounts were estimated based on the joint application of seven categories of PCPs (body and hair wash, toilet soaps, shaving products, dentifrices, deodorants, moisturizers and perfumes), while for children only four categories were taken into account (body and hair wash, toilet soaps, dentifrices and moisturizers).

The parameters used to determine the dermal exposure as amount of product used per application, frequency of application and retention factors, were established based on data obtained from other European Union surveys (Biesterbos et al., 2013; Bremmer et al., 2006; Gomez-Berrada et al., 2013; Gosens et al., 2014; Scientific Committee on Consumer Safety, 2012). However, the permeation factor that reflects the percutaneous absorption of synthetic musks is a parameter that is not easy to determine because it depends either on the chemical properties (e.g. $\log \mathrm{K}_{\mathrm{ow}}$, molecular weight) of the target compounds or on their behaviour in the vehicle (Parliament, 2013). In fact, information on dermal absorption of synthetic musks is very scarce. Ford et al. (1999) studied the systemic exposure to the polycyclic musks, AHTN and HHCB, through the application of alcoholic solutions in humans. They verify that total absorbed dose was approximately 1 and $0.1 \%$ for tonalide and galaxolide, respectively. On the other hand, Hawkins et al. (2002) studied the systemic exposure of three nitromusks. Means of $2.0 \%$ musk ambrette, $0.5 \%$ musk ketone and $0.3 \%$ musk xylene were absorbed. According to Slanina (2004), in vivo studies in human volunteers or in models using human skin show that adsorption rates of individual musks are in the range of $0.3-5 \%$. Therefore, taking into account the uncertainties concerning the rate of penetration of these chemicals through the skin and their variability with the vehicle, an average permeation factor of $10 \%$ was considered in this work.

As can be seen in Table 2, the average and maximum dermal exposure for adults to synthetic musks would be 75.69 and $283.99 \mu \mathrm{g} \mathrm{kg} \mathrm{bw}^{-1}$ day $^{-1}$, respectively. Assuming $10 \%$ as dermal absorption rate, $7.57 \mu \mathrm{g} \mathrm{kg} \mathrm{bw}^{-1} \mathrm{day}^{-1}$ (average) and $28.40 \mu \mathrm{g} \mathrm{kg} \mathrm{bw}^{-1}$ day $^{-1}$ (maximum) would be 
available for systemic absorption. Among the considered product subcategories, the main contributors for adult dermal exposure were perfumes with a maximum of $169.51 \mu \mathrm{g} \mathrm{kg} \mathrm{bw}^{-1}$ day $^{-}$ ${ }^{1}$, accounting for $60 \%$ of the aggregate daily dermal exposure, and body moisturizers with 105.01 $\mu \mathrm{g} \mathrm{kg} \mathrm{bw}{ }^{-1}$ day $^{-1}$ (37\%). Exposure to synthetic musks through the other toiletry products is negligible, accounting with less than $3 \%$ to the total daily dermal exposure. About $40 \%$ of the adult daily dermal exposure is related to EXA, $30 \% \mathrm{HHCB}$, and $15 \%$ AHTN.

Roosens et al. (2007) calculated the dermal exposure to HHCB, AHTN, MX and MK based on different personal care products bought in Belgium (body lotions, perfumes, deodorants, hair care products, shower products and sanitation products). They estimated an average daily exposure of $125 \mu \mathrm{g} \mathrm{kg} \mathrm{bw}^{-1} \mathrm{day}^{-1}$, about three times higher than those determined in the present study $\left(\mathrm{D}_{\exp \mathrm{HHCB}+\mathrm{AHTN}+\mathrm{MK}+\mathrm{MX}}=36 \mu \mathrm{g} \mathrm{kg} \mathrm{bw}^{-1} \mathrm{day}^{-1}\right)$. These authors also verified that HHCB was the highest contributor to the exposure (around 75\%) and the input of nitromusks was very scarce, less than $2 \%$. Similarly to this study, they verified that perfumes were major sources of human dermal exposure.

An exposure study for HHCB, AHTN, MK and MX was also developed by Lu et al. (2011) in China. They concluded that each person is exposed to around $57 \mu \mathrm{g} \mathrm{kg} \mathrm{bw}^{-1}$ day $^{-1}$ of these synthetic musks and the shampoo contributed with the highest exposure rate (83\%). These small differences could be explained by the use of different products, reflecting the different usage of personal care products (habits) according to the geographical distribution. Among all of the studied synthetic musk compounds, $\mathrm{HHCB}$ was the largest contributor to the total exposure $\left(51 \mu \mathrm{g} \mathrm{kg} \mathrm{bw}^{-1}\right.$ day $\left.^{-1}\right)$ while the contribution of nitromusks was 2 to 4 orders of magnitude lower. The aggregated daily dermal exposure to HHCB was also determined in Portugal by Correia et al. (2013). Considering a typical adult consume profile, they estimated the daily exposure to HHCB in $50 \mu \mathrm{g} \mathrm{kg} \mathrm{bw}^{-1}$ day $^{-}$ 1, exclusively using the seven analysed toiletries. The result was similar to that obtained for Lu et al. (2011) and in the same order of magnitude of the current work.

A daily uptake for different macrocyclic and polycyclic musks was studied by Nakata et al. (2015), using commercial cosmetics collected from Japan. These authors reported a daily dermal uptake of $7.8 \mu \mathrm{g} \mathrm{kg} \mathrm{bw}^{-1} \mathrm{day}^{-1}$ for EB and $7.9 \mu \mathrm{g} \mathrm{kg} \mathrm{bw}^{-1} \mathrm{day}^{-1}$ for HHCB. Lower values were 
reported for habanolide $\left(1.1 \mu \mathrm{g} \mathrm{kg} \mathrm{bw}^{-1} \mathrm{day}^{-1}\right)$, EXA $\left(1.5 \mu \mathrm{g} \mathrm{kg} \mathrm{bw}{ }^{-1}\right.$ day $\left.^{-1}\right)$, OTNE $\left(4.9 \mu \mathrm{g} \mathrm{kg} \mathrm{bw}^{-1}\right.$ day $\left.^{-1}\right)$ and AHTN $\left(2.3 \mu \mathrm{g} \mathrm{kg} \mathrm{bw}^{-1} \mathrm{day}^{-1}\right)$. These results are in the same order of magnitude of those found in this study. The same dominant sources of exposure were found: perfumes and body lotions.

Babies and young children due to their development status present a thinner and less impervious skin, making them a more vulnerable group. In those cases, dermal exposure may be a significant pathway for this type of contaminants and such exposure can cause adverse effects in these underdeveloped body systems. Therefore, the daily dermal exposure to synthetic musks for this group was also estimated (Table 3). In this study, an average daily dermal exposure to synthetic musks of $15.54 \mu \mathrm{g} \mathrm{kg} \mathrm{bw}^{-1}$ day $^{-1}$ was estimated, whereas in the worst-case scenario baby/children is exposed to $45.41 \mu \mathrm{g} \mathrm{kg} \mathrm{bw}^{-1} \mathrm{day}^{-1}$. Undoubtedly the baby lotions (including those used for diaper dermatitis) are the main contributors (97\%). Dermal exposure occurs mainly to EXA (96\%). Due to the lack of information, the daily dermal uptake for baby/children was also estimated assuming a penetration factor of $10 \%$, which results in a maximum value of about 4.54 $\mu \mathrm{gg}_{\mathrm{bw}}{ }^{-1} \mathrm{day}^{-1}$.

In this study, children's exposure to synthetic musks was about five times lower compared to adults' exposure. A similar comparison (children $v s$. adults) was also performed for the same product type (Figure 3). As can be seen, dermal exposure to synthetic musks using body moisturizers and shampoos were higher in adults, while toothpaste and shower gel represented a larger share in the children's exposure. Similar results in toilet soaps were found for both age categories. To the authors' best knowledge, this is the first study that estimates the daily dermal exposure to this sensitive class.

\subsection{Estimates of environmental discharges}

Considering the aggregated consumption pattern of personal care products presented above for the adult population, the amount of synthetic musks released "down-the-drain" into the wastewater treatment systems was estimated. Emissions were calculated based on either direct release of wash-off products during the shower or the indirect release of leave-on products. The latter are applied to the skin and after use, synthetic musks undergo evaporation. Those that 
remain on the skin will then be rinsed in the next shower. To perform these calculations, it was assumed that an average person applies the leave-on products approximately once every $24 \mathrm{~h}$. Therefore, the emission "down-the-drain" per capita was evaluated according to the Eq.3 (adapted from Gouin et al., 2013):

$$
E m=\sum_{i=1}^{n} \sum_{j=1}^{m} C_{j} \times A_{i} \times F_{i} \times\left(1-R_{i}\right)+\sum_{i=1}^{n} \sum_{j=1}^{m} C_{j} \times A_{i} \times F_{i} \times R_{i} \times\left(1-F_{\text {dermal }}\right) \times\left(1-F_{\text {evap }}\right)
$$

where $E m$ : estimated "down-the-drain" emission per capita, $F_{\text {evap }}$ : evaporation factor that reflects the volatilization potential from the skin surface in $24 \mathrm{~h}$. No information is available for evaporation rate of synthetic musks from skin. Due to their similarity with siloxanes, it was assumed a value of 95\% (Montemayor et al., 2013). The main results are presented in Table 4.

An average "down-the-drain" emission per capita of around $6.7 \mathrm{mg} \mathrm{day}^{-1}$ was estimated for synthetic musks, whereas a maximum value of $44.7 \mathrm{mg} \mathrm{day}^{-1}$ is expected. Due to the significant loss of these organic compounds, the leave-on products do not contribute significantly $(<3 \%)$ to the mass loading of wastewater treatment systems. However, the wash-off products represent the greater emission source (97\%). For instance, the shampoo contributes for $71 \%$ of the emissions (mean: $4.3 \mathrm{mg}_{\text {capita }}{ }^{-1}$ day $^{-1}$; maximum: $34.9 \mathrm{mg}$ capita $^{-1}$ day $\left.^{-1}\right)$, followed by the shower gel $(17 \%$; mean: $1.3 \mathrm{mg}_{\text {capita }}{ }^{-1}$ day $^{-1}$; maximum: $7.0 \mathrm{mg} \mathrm{capita}^{-1}$ day $^{-1}$ ) and hair conditioner ( $5 \%$; mean: 0.3 mg capita ${ }^{-1}$ day $^{-1}$; maximum: $0.9 \mathrm{mg}_{\text {capita }}{ }^{-1}$ day $\left.^{-1}\right)$.

HHCB (75\%), EXA (16\%), DPMI and AHTN (5\% each) were the predominant compounds in these emission effluents, contributing in average with $4.9 \mathrm{mg}$ capita $^{-1}$ day $^{-1}, 1.1 \mathrm{mg}$ capita $^{-1}$ day $^{-}$ ${ }^{1}$ and $0.3 \mathrm{mg} \mathrm{capita}^{-1}$ day $^{-1}$, respectively. Comparing these results with the literature, it can be found consistent levels. Mass loads for AHTN are usually lower than for HHCB, with values ranging from 0.1 to $0.8 \mathrm{mg}$ capita $^{-1}$ day $^{-1}$ and from 0.2 to $2.7 \mathrm{mg}$ capita $^{-1} \mathrm{day}^{-1}$, respectively (Homem et al., 2015; Clara et al., 2011; Lv et al., 2010; Zhang et al., 2008; Horii et al., 2007; Yang and Metcalf, 2006; Bester, 2004; Kupper et al., 2004). 


\section{Conclusions}

The concentration levels of synthetic musks in different adult and baby/children PCPs (body and hair wash, toilet soaps, shaving products, dentifrice products, deodorants/antiperspirants, moisturizers and perfumes) were investigated in Portugal. They were detected in all analysed samples in a broad concentration range $\left(0.01 \mathrm{ng} \mathrm{g}^{-1}\right.$ to $\left.30 \mathrm{mg} \mathrm{g}^{-1}\right)$. Polycyclic and macrocyclic musks were more frequently detected than the nitromusks. In fact, galaxolide, exaltolide and cashmeran were the most detected compounds. The higher concentrations were found in perfumes (5245.05 $\left.\mu \mathrm{g} \mathrm{g}^{-1}\right)$, shampoos (487.67 $\left.\mu \mathrm{g} \mathrm{g}^{-1}\right)$, body moisturizers $\left(154.13 \mu \mathrm{g} \mathrm{g}^{-1}\right)$ and hair conditioners $\left(66.43 \mu \mathrm{g} \mathrm{g}^{-1}\right)$ for adults, while the lowest were detected in toothpastes $\left(0.02 \mu \mathrm{g} \mathrm{g}^{-1}\right)$. Personal care products for babies and children presented lower levels than products for adults.

Dermal exposure was estimated based on the concentrations of synthetic musks in the studied personal care products and the average daily usage amounts of those consumer products. The estimated adult daily dermal exposure to synthetic musks was calculated as $75.69 \mu \mathrm{g} \mathrm{kg} \mathrm{bw}^{-1}$ day $^{-}$

1. Children's exposure was about five times lower compared to adults' exposure $\left(15.54 \mu \mathrm{g} \mathrm{kg} \mathrm{bw}^{-1}\right.$ day $\left.^{-1}\right)$. Finally, considering the studied aggregated consumption pattern of adult personal care products, the amount of synthetic musks released "down-the-drain" into the wastewater treatment systems was estimated. It is expected, an average emission per capita of $6.7 \mathrm{mg} \mathrm{day}^{-1}$, being the wash-off products the greater source. Galaxolide and exaltolide will be the predominant musks in the emission effluents.

\section{Conflicts of interest statement}

The authors declare there are no conflicts of interest.

\section{Acknowledgments}

This work was funded by FEDER funds through the Operational Programme for Competitiveness Factors - COMPETE, ON.2 - O Novo Norte - North Portugal Regional Operational Programme and National Funds through FCT - Foundation for Science and 
Technology under the projects: PEst-C/EQB/UI0511, NORTE-07-0124-FEDER-000025 - RL2_ Environment\&Health. Vera Homem would like to thank Fundação para a Ciência e a Tecnologia (FCT - Portugal) for the post-doctoral grant SFRH/BPD/76974/2011 co-funded by the QRENPOPH.

\section{References}

Arbulu, M., Sampedro, M.C., Unceta, N., Gomez-Caballero, A., Goicolea, M.A., Barrio, R.J., 2011. A retention time locked gas chromatography-mass spectrometry method based on stir-bar sorptive extraction and thermal desorption for automated determination of synthetic musk fragrances in natural and wastewaters. J. Chromatogr. A 1218, 3048-3055.

Bester, K., 2004. Retention characteristics and balance assessment for two polycyclic musk fragrances (HHCB and AHTN) in a typical German sewage treatment plant. Chemosphere 57, 863-870.

Bester, K., 2009. Analysis of musk fragrances in environmental samples. J. Chromatogr. A $1216,470-480$.

Biesterbos, J.W., Dudzina, T., Delmaar, C.J., Bakker, M.I., Russel, F.G., von Goetz, N., Scheepers, P.T., Roeleveld, N., 2013. Usage patterns of personal care products: important factors for exposure assessment. Food Chem. Toxicol. 55, 8-17.

Bremmer, H.J., Lodder, L.C.H.P.h.d., Engelen, J.G.M.v., 2006. Cosmetics Fact Sheet. To assess the risks for the consumer. Updated version for ConsExpo 4, RIVM.

Cadby, P.A., Troy, W.R., Middleton, J.D., Vey, M.G.H., 2002. Fragrances: are they safe? Flavour Frag. J. 17, 472-477.

Clara, M., Gans, O., Windhofer, G., Krenn, U., Hartl, W., Braun, K., Scharf, S., Scheffknecht, C., 2011. Occurrence of polycyclic musks in wastewater and receiving water bodies and fate during wastewater treatment. Chemosphere 82, 1116-1123.

Correia, P., Cruz, A., Santos, L., Alves, A., 2013. Human dermal exposure to galaxolide from personal care products. Int. J. Cosmet. Sci. 35, 299-309. 
Dong, H., Tang, H., Chen, D., Xu, T., Li, L., 2014. Analysis of 7 synthetic musks in cream by supported liquid extraction and solid phase extraction followed by GC-MS/MS. Talanta 120, 248254.

European Parliament, 2009. Regulation (EC) No 1223/2009 of the European Parliament and of the Council of 30 November 2009 on cosmetic products, Official Journal of the European Union, L342, pp. 59-209.

Ford, R.A., Hawkins, D.R., Schwarzenbach, R., Api, A.M., 1999. The systemic exposure to the polycyclic musks, AHTN and $\mathrm{HHCB}$, under conditions of use as fragrance ingredients: evidence of lack of complete absorption from a skin reservoir. Toxicol. Lett. 111, 133-142.

Gomez-Berrada, M.P., Gautier, F., Parent-Massin, D., Ferret, P.J., 2013. Retrospective exposure data for baby and children care products: an analysis of 48 clinical studies. Food Chem. Toxicol. 57, 185-194.

Gosens, I., Delmaar, C.J., Ter Burg, W., de Heer, C., Schuur, A.G., 2014. Aggregate exposure approaches for parabens in personal care products: a case assessment for children between 0 and 3 years old. J. Expo. Sci. Environ. Epidemiol. 24, 208-214.

Gouin, T., van Egmond, R., Sparham, C., Hastie, C., Chowdhury, N., 2013. Simulated use and wash-off release of decamethylcyclopentasiloxane used in anti-perspirants. Chemosphere 93, 726-734.

Hawkins, D.R., Elsom, L.F., Kirkpatrick, D., Ford, R.A., Api, A.M., 2002. Dermal absorption and disposition of musk ambrette, musk ketone and musk xylene in human subjects. Toxicol. Lett. $131,147-151$

Homem, V., Silva, J.A., Cunha, C., Alves, A., Santos, L., 2013. New analytical method for the determination of musks in personal care products by Quick, Easy, Cheap, Effective, Rugged, and Safe extraction followed by GC-MS. J. Sep. Sci. 36, 2176-2184.

Homem, V., Silva, J.A., Ratola, N., Santos, L., Alves, A., 2015. Long lasting perfume-a review of synthetic musks in WWTPs. J. Environ. Manage. 149, 168-192. 
Horii, Y., Reiner, J.L., Loganathan, B.G., Kumar, K.S., Sajwan, K., Kannan, K., 2007. Occurrence and fate of polycyclic musks in wastewater treatment plants in Kentucky and Georgia, USA. Chemosphere 68, 2011-2020.

Hutter, H.P., Wallner, P., Hartl, W., Uhl, M., Lorbeer, G., Gminski, R., Mersch-Sundermann, V., Kundi, M., 2010. Higher blood concentrations of synthetic musks in women above fifty years than in younger women. Int. J. Hyg. Environ. Health 213, 124-130.

Hutter, H.P., Wallner, P., Moshammer, H., Hartl, W., Sattelberger, R., Lorbeer, G., Kundi, M., 2005. Blood concentrations of polycyclic musks in healthy young adults. Chemosphere 59, 487492.

Hutter, H.P., Wallner, P., Moshammer, H., Hartl, W., Sattelberger, R., Lorbeer, G., Kundi, M., 2009. Synthetic musks in blood of healthy young adults: relationship to cosmetics use. Sci. Tot. Environ. 407, 4821-4825.

Kang, C.S., Lee, J.H., Kim, S.K., Lee, K.T., Lee, J.S., Park, P.S., Yun, S.H., Kannan, K., Yoo, Y.W., Ha, J.Y., Lee, S.W., 2010. Polybrominated diphenyl ethers and synthetic musks in umbilical cord serum, maternal serum, and breast milk from Seoul, South Korea. Chemosphere $80,116-122$.

Kupper, T., Berset, J.D., Etter-Holzer, R., Furrer, R., Tarradellas, J., 2004. Concentrations and specific loads of polycyclic musks in sewage sludge originating from a monitoring network in Switzerland. Chemosphere 54, 1111-1120.

Lee, I.S., Lee, S.H., Oh, J.E., 2010. Occurrence and fate of synthetic musk compounds in water environment. Water Res. 44, 214-222.

Llompart, M., Celeiro, M., Pablo Lamas, J., Sanchez-Prado, L., Lores, M., Garcia-Jares, C., 2013. Analysis of plasticizers and synthetic musks in cosmetic and personal care products by matrix solid-phase dispersion gas chromatography-mass spectrometry. J. Chromatogr. A 1293, $10-19$.

Lu, Y., Yuan, T., Wang, W., Kannan, K., 2011. Concentrations and assessment of exposure to siloxanes and synthetic musks in personal care products from China. Environ. Pollut. 159, 35223528. 
Lv, Y., Yuan, T., Hu, J., Wang, W., 2010. Seasonal occurrence and behavior of synthetic musks (SMs) during wastewater treatment process in Shanghai, China. Sci. Tot. Environ. 408, $4170-4176$.

Montemayor, B.P., Price, B.B., van Egmond, R.A., 2013. Accounting for intended use application in characterizing the contributions of cyclopentasiloxane (D5) to aquatic loadings following personal care product use: antiperspirants, skin care products and hair care products. Chemosphere 93, 735-740.

Nakata, H., Hinosaka, M., Yanagimoto, H., 2015. Macrocyclic-, polycyclic-, and nitro musks in cosmetics, household commodities and indoor dusts collected from Japan: implications for their human exposure. Ecotoxicol. Environ. Saf. 111, 248-255.

Parliament, E., 2013. Commission Implementing Decision of 25 November 2013 on Guidelines on Annex I to Regulation (EC) No 1223/2009 of the European Parliament and of the Council on cosmetic products. Official Journal of the European Union L315, 82-105.

Reiner, J.L., Kannan, K., 2006. A survey of polycyclic musks in selected household commodities from the United States. Chemosphere 62, 867-873.

Roosens, L., Covaci, A., Neels, H., 2007. Concentrations of synthetic musk compounds in personal care and sanitation products and human exposure profiles through dermal application. Chemosphere 69, 1540-1547.

Salvito, D., 2005. Synthetic Musk Compounds and Effects on Human Health? Environ. Health Perspect. 113, 802-803.

Sanchez-Prado, L., Llompart, M., Lamas, J.P., Garcia-Jares, C., Lores, M., 2011. Multicomponent analytical methodology to control phthalates, synthetic musks, fragrance allergens and preservatives in perfumes. Talanta $85,370-379$.

Schmeiser, H.H., Gminski, R., Mersch-Sundermann, V., 2001. Evaluation of health risks caused by musk ketone. Int. J. Hyg. Environ. Health 203, 293-299.

Scientific Committee on Consumer Safety, 2012. The SCCS'S Notes of Guidance for the Testing of Cosmetic Ingredients and Their Safety Evaluation, 8th revision, Brussels. 
Slanina, P., 2004. Risk evaluation of dietary and dermal exposure to musk fragrances. Springer-Verlag, Berlin.

Taylor, K.M., Weisskopf, M., Shine, J., 2014. Human exposure to nitro musks and the evaluation of their potential toxicity: an overview. Environ. Health 13, 14.

Wang, H., Zhang, J., Gao, F., Yang, Y., Duan, H., Wu, Y., Berset, J.D., Shao, B., 2011. Simultaneous analysis of synthetic musks and triclosan in human breast milk by gas chromatography tandem mass spectrometry. J. Chromatogr. B 879, 1861-1869.

Yang, J.-J., Metcalfe, C.D., 2006. Fate of synthetic musks in a domestic wastewater treatment plant and in an agricultural field amended with biosolids. Sci. Tot. Environ. 363, 149-165.

Yin, J., Wang, H., Zhang, J., Zhou, N., Gao, F., Wu, Y., Xiang, J., Shao, B., 2012. The occurrence of synthetic musks in human breast milk in Sichuan, China. Chemosphere 87, 10181023.

Zhang, X., Liang, G., Zeng, X., Zhou, J., Sheng, G., Fu, J., 2011. Levels of synthetic musk fragrances in human milk from three cities in the Yangtze River Delta in Eastern China. J. Environ. Sci. 23, 983-990.

Zhang, X., Yao, Y., Zeng, X., Qian, G., Guo, Y., Wu, M., Sheng, G., Fu, J., 2008. Synthetic musks in the aquatic environment and personal care products in Shanghai, China. Chemosphere $72,1553-1558$.

Zhou, J., Zeng, X., Zheng, K., Zhu, X., Ma, L., Xu, Q., Zhang, X., Yu, Y., Sheng, G., Fu, J., 2012. Musks and organochlorine pesticides in breast milk from Shanghai, China: levels, temporal trends and exposure assessment. Ecotoxicol. Environ. Saf. 84, 325-333.

\section{Figure Captions}

Nitromusks 
<smiles>Cc1c([N+](=O)[O-])c(C)c([N+](=O)[O-])c(C(C)(C)C)c1[N+](=O)[O-]</smiles>

Musk xylene (MX) CAS: $81-15-2$

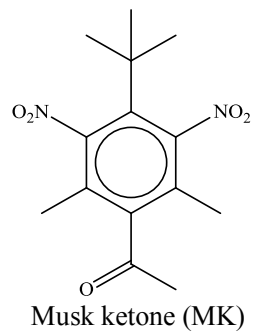

CAS: $81-14-1$

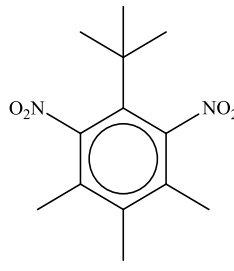

Musk tibetene (MT) CAS: $145-39-1$

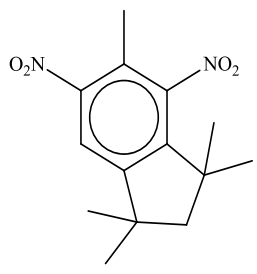

Musk moskene (MM) CAS: $116-66-5$

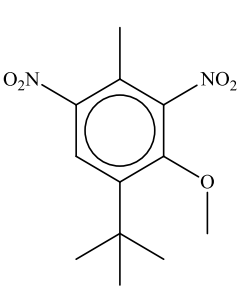

Musk ambrette (MA) CAS: $83-66-9$<smiles>CC(=O)c1cc2c(cc1C(C)(C)C)C(C)(C)C(C)C2(C)C</smiles>

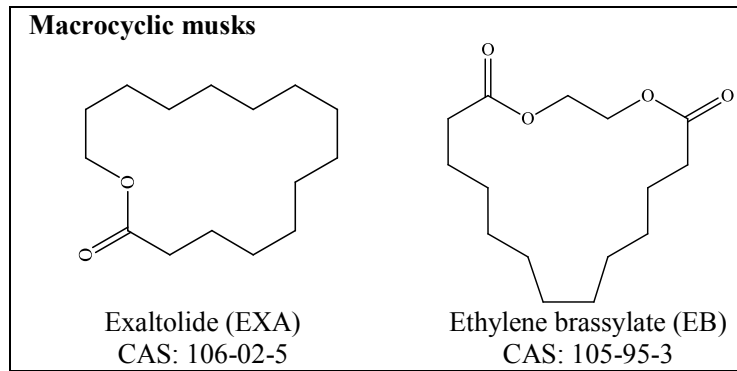

Figure 1. Chemical structure of synthetic musk fragrances analyzed in this study.

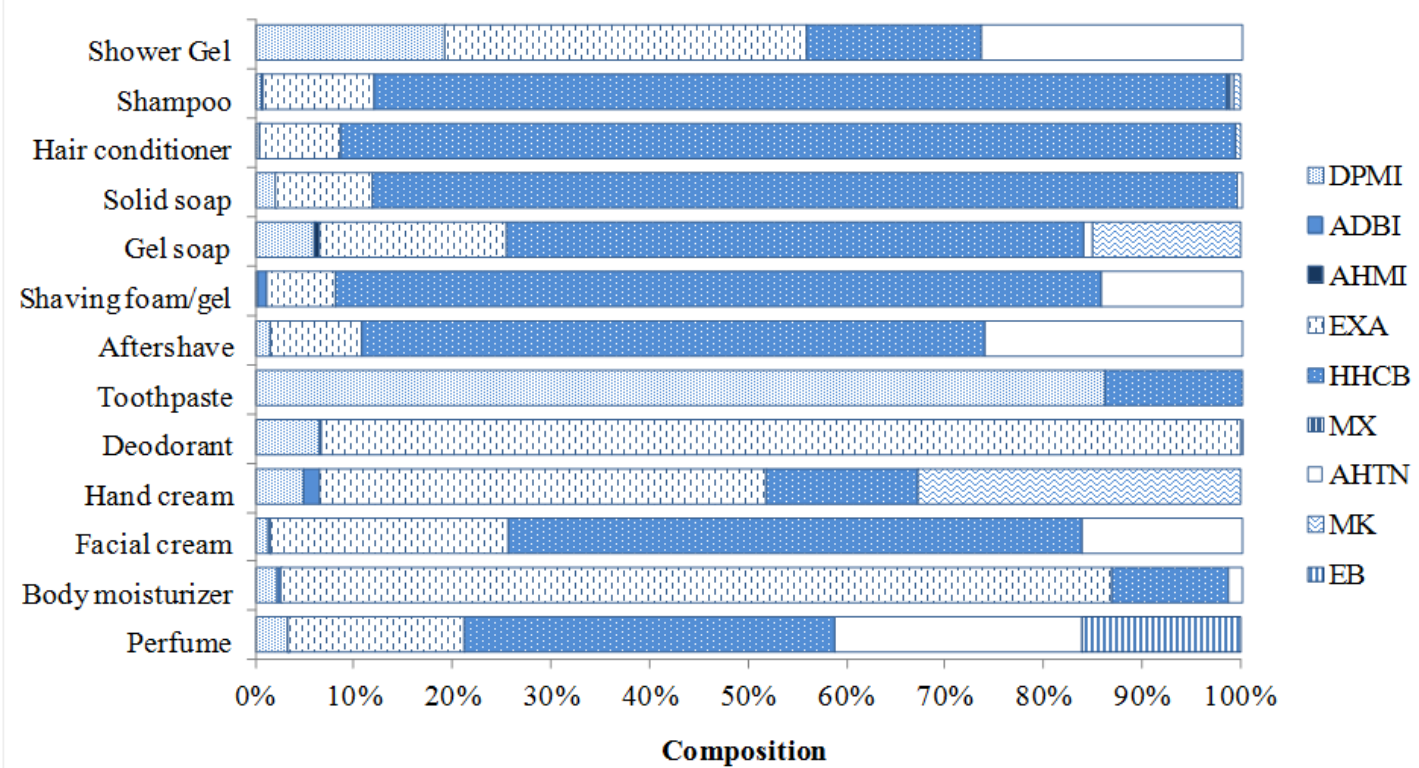

Figure 2. Relative distribution (\%) of synthetic musks in toiletries from Porto. 


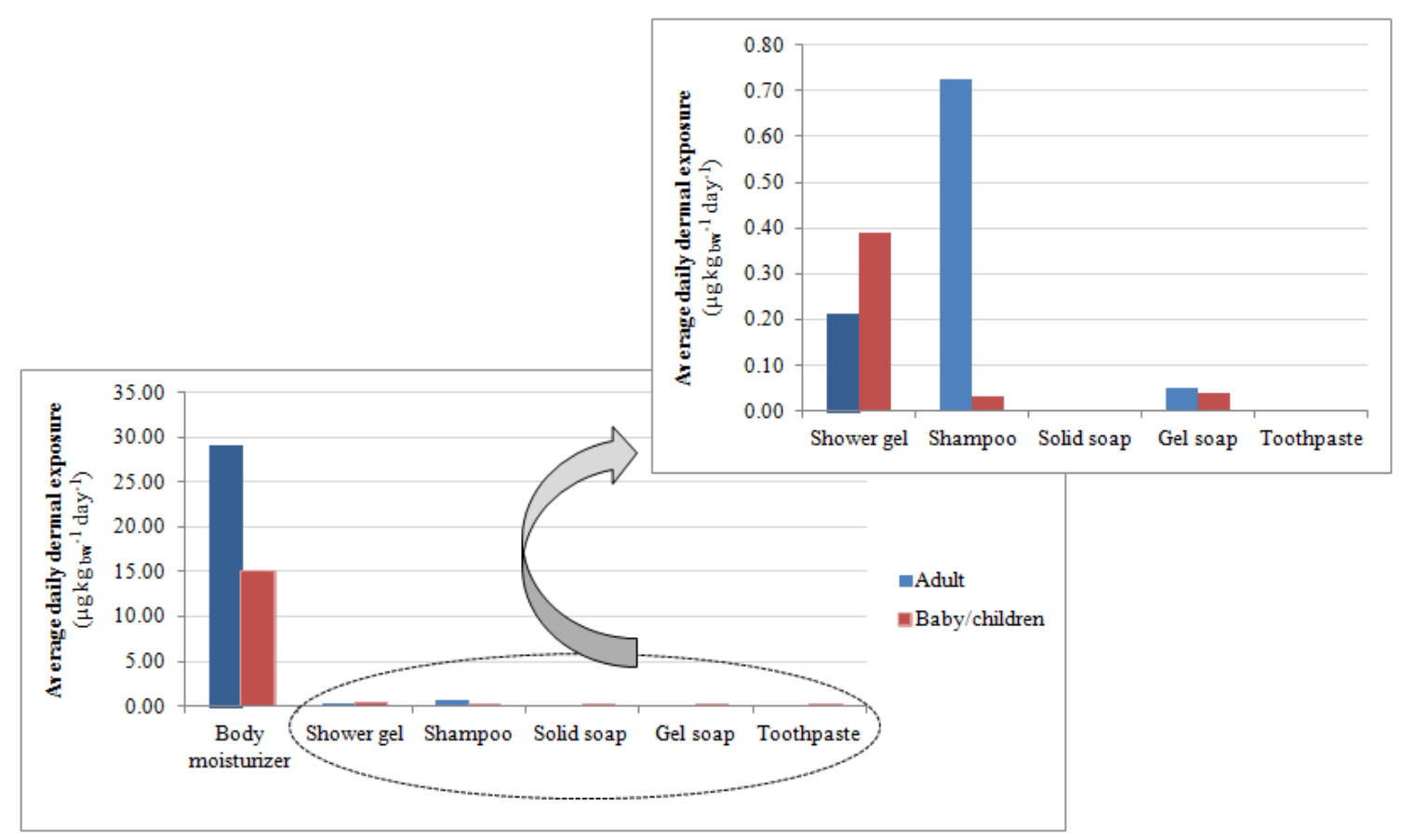

Figure 3. Comparison of dermal exposure to synthetic musks by age and personal care product category. 


\section{Table Captions}

2 Table 1. Concentrations ( $\mu \mathrm{g} \mathrm{g}^{-1}$; median, mean and range) and frequency of detection (\%) of the synthetic musks in toiletries from Porto, Portugal.

\begin{tabular}{|c|c|c|c|c|c|c|c|c|c|c|c|c|c|}
\hline Category & Product & $n$ & & ADBI & AHMI & AHTN & DPMI & ННСВ & MK & MX & EXA & EB & TOTAL \\
\hline \multirow{20}{*}{$\begin{array}{l}\text { Body and } \\
\text { Hair Wash }\end{array}$} & \multirow{4}{*}{ Adult shower gel } & \multirow{4}{*}{10} & Mean & 0.02 & nd & 54.46 & 59.84 & 89.65 & nd & nd & 83.57 & \multirow{4}{*}{--- } & 72.59 \\
\hline & & & Median & 0.02 & nd & 54.46 & 4.63 & 0.32 & nd & nd & 10.91 & & \multirow{3}{*}{$\begin{array}{l}6.41 \\
\text { nd - } 532.94\end{array}$} \\
\hline & & & Range & nd -0.02 & nd & nd - 54.46 & $0.05-512.66$ & nd -460.07 & nd & nd & nd -532.94 & & \\
\hline & & & Frequency & 10 & 0 & 10 & 100 & 70 & 0 & 0 & 90 & & \\
\hline & \multirow{4}{*}{$\begin{array}{l}\text { Baby/children shower } \\
\text { gel }\end{array}$} & \multirow{4}{*}{10} & Mean & nd & nd & nd & 0.57 & 0.08 & nd & nd & 66.21 & \multirow{4}{*}{--} & \multirow{4}{*}{$\begin{array}{l}21.23 \\
0.22 \\
\text { nd - } 309.75\end{array}$} \\
\hline & & & Median & nd & nd & nd & 0.61 & 0.02 & nd & nd & 6.21 & & \\
\hline & & & Range & nd & nd & nd & nd -1.05 & $0.0004-0.48$ & nd & nd & nd -309.75 & & \\
\hline & & & Frequency & 0 & 0 & 0 & 50 & 100 & 0 & 0 & 70 & & \\
\hline & \multirow{4}{*}{ Adult shampoo } & \multirow{4}{*}{11} & Mean & 1.05 & 1.01 & 5.08 & 9.17 & 1558.10 & nd & nd & 237.98 & \multirow{4}{*}{---} & \multirow{4}{*}{$\begin{array}{l}487.67 \\
2.62 \\
\text { nd - } 12861.33\end{array}$} \\
\hline & & & Median & 0.20 & 0.03 & 5.08 & 0.28 & 434.28 & nd & nd & 6.31 & & \\
\hline & & & Range & nd -5.50 & nd -4.90 & nd -5.08 & nd -52.48 & $<\mathrm{LOQ}-12861.33$ & nd & nd & nd - 1752.30 & & \\
\hline & & & Frequency & 55 & 45 & 9 & 55 & 100 & 0 & 0 & 73 & & \\
\hline & \multirow{4}{*}{$\begin{array}{l}\text { Baby/children } \\
\text { shampoo }\end{array}$} & \multirow{4}{*}{8} & Mean & nd & nd & nd & 0.69 & 3.52 & 6.59 & 3.42 & 2.38 & \multirow{4}{*}{--} & \multirow{4}{*}{$\begin{array}{l}2.97 \\
0.46 \\
\text { nd - } 20.83\end{array}$} \\
\hline & & & Median & nd & nd & nd & 0.26 & 0.06 & 6.59 & 3.42 & 1.95 & & \\
\hline & & & Range & nd & nd & nd & nd -1.63 & $<\mathrm{LOQ}-20.83$ & nd - 12.71 & nd -3.42 & nd -6.70 & & \\
\hline & & & Frequency & 0 & 0 & 0 & 38 & 100 & 25 & 13 & 88 & & \\
\hline & \multirow{4}{*}{ Hair conditioner } & \multirow{4}{*}{8} & Mean & 0.13 & 0.05 & nd & 0.97 & 229.92 & 1.38 & nd & 20.93 & \multirow{4}{*}{---} & \multirow{4}{*}{$\begin{array}{l}66.43 \\
0.47 \\
\text { nd - } 405.36\end{array}$} \\
\hline & & & Median & 0.12 & 0.001 & nd & 0.15 & 285.69 & 1.38 & nd & 12.21 & & \\
\hline & & & Range & nd -0.21 & nd -0.14 & nd & nd -3.05 & $0.01-405.36$ & nd -1.38 & nd & nd - 50.91 & & \\
\hline & & & Frequency & 75 & 38 & 0 & 63 & 100 & 13 & 0 & 88 & & \\
\hline \multirow{8}{*}{ Toilet Soaps } & \multirow{4}{*}{ Solid soap } & \multirow{4}{*}{8} & Mean & 0.01 & $<\mathrm{LOQ}$ & 0.02 & 0.16 & 6.97 & nd & nd & 0.78 & & 2.60 \\
\hline & & & Median & 0.01 & $<\mathrm{LOQ}$ & 0.02 & 0.13 & 1.73 & nd & nd & 0.82 & & 0.10 \\
\hline & & & Range & nd -0.01 & nd $-<$ LOQ & nd -0.03 & nd -0.31 & $0.004-38.00$ & nd & nd & nd -1.45 & -- & nd -38.00 \\
\hline & & & Frequency & 25 & 13 & 50 & 75 & 100 & 0 & 0 & 50 & & \\
\hline & & & Mean & 0.02 & 0.32 & 0.64 & 4.08 & 39.67 & 10.10 & nd & 12.88 & & 14.68 \\
\hline & & & Median & 0.02 & 0.32 & 0.49 & 0.52 & 23.53 & 10.10 & nd & 4.07 & & 1.03 \\
\hline & Gel soap & 7 & Range & nd -0.03 & nd -0.35 & nd -1.18 & nd - 18.74 & $0.02-106.50$ & nd -17.87 & nd & $0.78-53.59$ & -- & nd -106.50 \\
\hline & & & Frequency & 29 & 29 & 43 & 71 & 100 & 29 & 0 & 100 & & \\
\hline & & & Mean & 0.36 & nd & 5.45 & 0.11 & 30.00 & nd & nd & 2.64 & & 10.75 \\
\hline & & & Median & 0.36 & nd & & 0.11 & 4.21 & nd & nd & & & 0.91 \\
\hline & Shaving foam/gel & 6 & Range & nd -0.36 & nd & nd -14.47 & nd -0.18 & $<$ LOQ - 138.27 & nd & nd & $0.23-9.95$ & -- & nd -138.27 \\
\hline Shaving & & & Frequency & 17 & 0 & 50 & 33 & 100 & 0 & 0 & 100 & & \\
\hline Products & & & Mean & nd & nd & 8.10 & 0.49 & 19.70 & nd & nd & 2.86 & & 9.53 \\
\hline & & & Median & nd & nd & 8.10 & 0.49 & 5.87 & nd & nd & 1.94 & & 1.81 \\
\hline & Aftershave & 6 & Range & nd & nd & nd -15.75 & nd -0.72 & $0.003-55.35$ & nd & nd & $1.03-7.90$ & -- & nd -55.35 \\
\hline & & & Frequency & 0 & 0 & 33 & 33 & 100 & 0 & 0 & 100 & & \\
\hline
\end{tabular}


3 Table 2. Estimated human exposure (adults) to synthetic musks through personal care products.

\begin{tabular}{|c|c|c|c|c|c|c|c|c|c|c|}
\hline \multirow[t]{2}{*}{ Category } & \multirow[t]{2}{*}{ Product type } & \multirow{2}{*}{$\begin{array}{l}\text { Amount per } \\
\text { application }^{\text {a }} \\
\left(\mathrm{g} \text { event }^{-1}\right)\end{array}$} & \multirow{2}{*}{$\begin{array}{l}\text { Frequency of } \\
\text { application a } \\
\text { (events day-1) }\end{array}$} & \multirow[t]{2}{*}{$\begin{array}{l}\text { Retention } \\
\text { factor }^{c}\end{array}$} & \multicolumn{2}{|c|}{$\begin{array}{c}\text { Total concentration of } \\
\text { synthetic musks } \\
\left(\mu \mathrm{g} \mathrm{g}^{-1}\right)\end{array}$} & \multicolumn{2}{|c|}{$\begin{array}{l}\text { Daily dermal exposure } \\
\quad\left(\mu \mathrm{kg}_{\mathrm{bw}}^{-1} \mathrm{day}^{-1}\right)\end{array}$} & \multicolumn{2}{|c|}{$\begin{array}{l}\text { Daily dermal intake } \\
\qquad\left(\mu \mathrm{g} \mathrm{kg}_{\mathrm{bw}}{ }^{-1} \mathrm{day}^{-1}\right)\end{array}$} \\
\hline & & & & & Mean & Maximum & Mean & Maximum & Mean & Maximum \\
\hline \multirow{3}{*}{ Body and Hair Wash } & Shower gel & 6.30 & 0.71 & 0.01 & 288 & 1560 & 0.21 & 1.16 & 0.02 & 0.12 \\
\hline & Shampoo & 4.80 & 0.50 & 0.01 & 1812 & 14682 & 0.73 & 5.87 & 0.07 & 0.59 \\
\hline & Hair conditioner & 4.90 & 0.43 & 0.01 & 253 & 461 & 0.09 & 0.16 & 0.01 & 0.02 \\
\hline \multirow{2}{*}{ Toilet soaps } & Solid soap & $0.80^{\mathrm{b}}$ & $0.50^{\mathrm{b}}$ & 0.01 & 8 & 40 & 0.001 & 0.003 & 0.0001 & 0.00001 \\
\hline & Gel soap & $1.00^{\mathrm{b}}$ & $4.50^{\mathrm{b}}$ & 0.01 & 68 & 198 & 0.05 & 0.1 & 0.005 & 0.02 \\
\hline \multirow{2}{*}{ Shaving products } & Shaving foam/gel & 3.55 & 0.43 & 0.01 & 39 & 163 & 0.01 & 0.04 & 0.001 & 0.004 \\
\hline & Aftershave & 0.80 & 0.46 & 1.00 & 31 & 80 & 0.19 & 0.49 & 0.02 & 0.05 \\
\hline Dentifrice products & Toothpaste & 1.10 & 2.00 & 0.05 & 0.04 & 0.06 & 0.0001 & 0.0001 & 0.00001 & 0.00001 \\
\hline Deodorants / Antiperspirants & Roll-on deodorant & 0.20 & 1.00 & 1.00 & 55 & 147 & 0.18 & 0.49 & 0.02 & 0.05 \\
\hline \multirow{3}{*}{ Moisturizers } & Hand cream & 0.50 & 0.80 & 1.00 & 51 & 86 & 0.34 & 0.57 & 0.03 & 0.06 \\
\hline & Facial cream & 0.40 & 0.88 & 1.00 & 66 & 91 & 0.38 & 0.53 & 0.04 & 0.05 \\
\hline & Body lotion/milk/cream & 8.50 & 0.42 & 1.00 & 489 & 1765 & 29.07 & 105.01 & 2.91 & 10.50 \\
\hline \multirow[t]{2}{*}{ Perfumes } & Perfume/Eau de toilette & 0.10 & 1.00 & 1.00 & 26658 & 101708 & 44.43 & 169.51 & 4.44 & 16.95 \\
\hline & & & & & \multicolumn{2}{|c|}{ TOTAL $\left(\mu \mathrm{g} \mathrm{kg}_{b^{-1}}{ }^{-1} \mathrm{day}^{-1}\right)$} & 75.69 & 283.99 & 7.57 & 28.40 \\
\hline
\end{tabular}

4

5 Table 3. Estimated human exposure (baby/children) to synthetic musks through personal care products.

\begin{tabular}{|c|c|c|c|c|c|c|c|c|c|}
\hline \multirow[t]{2}{*}{ Category } & \multirow[t]{2}{*}{ Product type } & \multirow{2}{*}{$\begin{array}{l}\text { Amount per } \\
\text { application a } \\
\left(\mathrm{g} \text { event }{ }^{-1}\right)\end{array}$} & \multirow{2}{*}{$\begin{array}{l}\text { Frequency of } \\
\text { application a } \\
\left(\text { events day }{ }^{-1}\right)\end{array}$} & \multirow{2}{*}{$\begin{array}{c}\text { Retention } \\
\text { factor }\end{array}$} & $\begin{array}{l}\text { Total concentration of } \\
\text { synthetic musks } \\
\left(\mu \mathrm{g} \mathrm{g}^{-1}\right)\end{array}$ & \multicolumn{2}{|c|}{$\begin{array}{l}\text { Daily dermal exposure } \\
\qquad\left(\mu \mathrm{kg}_{\mathrm{bw}^{-1}}{ }^{-1} \mathrm{day}^{-1}\right)\end{array}$} & \multicolumn{2}{|c|}{$\begin{array}{l}\text { Daily dermal intake } \\
\qquad\left(\mu \mathrm{kg}_{\mathrm{bw}^{-1}} \mathrm{day}^{-1}\right)\end{array}$} \\
\hline & & & & & Maximum & Mean & Maximum & Mean & Maximum \\
\hline
\end{tabular}




\begin{tabular}{|c|c|c|c|c|c|c|c|c|c|c|}
\hline \multirow{2}{*}{ Body and Hair Wash } & Shower gel & 10.29 & 1.23 & 0.01 & 66.85 & 311.28 & 0.39 & 1.81 & 0.04 & 0.18 \\
\hline & Shampoo & 7.30 & 0.60 & 0.01 & 16.60 & 45.30 & 0.03 & 0.09 & 0.003 & 0.01 \\
\hline \multirow{2}{*}{ Toilet soaps } & Solid soap & $0.25^{\mathrm{b}}$ & $0.50^{\mathrm{b}}$ & 0.01 & 7.93 & 39.80 & 0.001 & 0.002 & 0.0001 & 0.0002 \\
\hline & Gel soap & $0.29^{\mathrm{b}}$ & $4.50^{\mathrm{b}}$ & 0.01 & 67.70 & 198.26 & 0.04 & 0.12 & 0.004 & 0.01 \\
\hline Dentifrice products & Toothpaste & 0.53 & 2.00 & 1.00 & 0.06 & 0.08 & 0.003 & 0.004 & 0.0003 & 0.0004 \\
\hline \multirow[t]{2}{*}{ Moisturizers } & $\begin{array}{l}\text { Body lotion/milk/cream } \\
\text { + diaper dermatitis } \\
\text { treatment }\end{array}$ & 4.53 & 2.00 & 1.00 & 36.11 & 103.95 & 15.07 & 43.39 & 1.51 & 4.34 \\
\hline & & & & & \multicolumn{2}{|c|}{ TOTAL $\left(\mu \mathrm{g} \mathrm{kg}_{\mathrm{bw}^{-1}} \mathrm{day}^{-1}\right)$} & 15.54 & 45.41 & 1.55 & 4.54 \\
\hline
\end{tabular}

6

7

8

9 
Table 4. Estimates of "down-the-drain" synthetic musks emissions for several personal care sub-category product types.

\begin{tabular}{|c|c|c|c|c|c|c|c|c|c|c|}
\hline \multirow[b]{2}{*}{ Category } & \multirow[b]{2}{*}{ Product type } & \multicolumn{9}{|c|}{ Estimated average per capita down-the-drain emission $\left(\mu \mathrm{g}\right.$ day $\left.^{-1}\right)$} \\
\hline & & DPMI & ADBI & AHMI & EXA & НHCВ & AHTN & MK & $\mathbf{E B}$ & $\begin{array}{r}\text { TOTAL } \\
\left(\mu \text { day }^{-1}\right)\end{array}$ \\
\hline \multirow{3}{*}{$\begin{array}{l}\text { Body and Hair } \\
\text { Wash }\end{array}$} & Shower gel & 265.13 & 0.10 & --- & 370.24 & 397.18 & 241.26 & --- & na & 1273.90 \\
\hline & Shampoo & 21.80 & 2.51 & 2.39 & 565.69 & 3703.72 & 12.08 & --- & na & 4308.19 \\
\hline & Hair conditioner & 2.02 & 0.27 & 0.10 & 43.69 & 479.81 & --- & 2.88 & na & 528.76 \\
\hline \multirow{2}{*}{ Toilet soaps } & Solid soap & 0.06 & 0.004 & --- & 0.31 & 2.76 & 0.01 & --- & na & 3.14 \\
\hline & Gel soap & 18.16 & 0.08 & 1.42 & 57.41 & 176.81 & 2.84 & 45.03 & na & 301.74 \\
\hline \multirow{2}{*}{ Shaving products } & Shaving foam/gel & 0.17 & 0.55 & --- & 3.99 & 45.36 & 8.24 & ---- & na & 58.30 \\
\hline & Aftershave & 0.01 & -- & -- & 0.05 & 0.33 & 0.13 & --- & na & 0.52 \\
\hline Dentifrice products & Toothpaste & 0.09 & --- & --- & 0.005 & -- & --- & --- & na & 0.09 \\
\hline $\begin{array}{l}\text { Deodorants / } \\
\text { Antiperspirants }\end{array}$ & Roll-on deodorant & 0.03 & --- & 0.001 & 0.46 & --- & --- & --- & na & 0.49 \\
\hline \multirow{3}{*}{ Moisturizers } & Hand cream & 0.05 & 0.01 & --- & 0.42 & 0.14 & -- & 0.30 & na & 0.92 \\
\hline & Facial cream & 0.02 & --- & 0.001 & 0.25 & 0.60 & 0.17 & --- & na & 1.03 \\
\hline & $\begin{array}{l}\text { Body } \\
\text { lotion/milk/cream }\end{array}$ & 1.41 & 0.23 & 0.002 & 58.63 & 16.57 & 1.66 & --- & na & 78.50 \\
\hline Perfumes & $\begin{array}{l}\text { Perfume/Eau de } \\
\text { toilette }\end{array}$ & 3.98 & 0.01 & 0.03 & 21.37 & 45.14 & 30.14 & --- & 19.29 & 119.96 \\
\hline \multicolumn{2}{|l|}{ TOTAL $\left(\mu \mathrm{g} \mathrm{day}^{-1}\right)$} & 312.91 & 3.75 & 3.95 & 1122.49 & 4868.42 & 296.52 & 48.21 & 19. & 6675.55 \\
\hline \multirow[b]{2}{*}{ Category } & \multirow[b]{2}{*}{ Product type } & \multicolumn{9}{|c|}{ Estimated maximum per capita down-the-drain emission $\left(\mu \mathrm{g} \mathrm{day}^{-1}\right)$} \\
\hline & & DPMI & ADBI & AHMI & EXA & НHСВ & AHTN & MK & EB & $\begin{array}{c}\text { TOTAL } \\
\left(\mu \mathrm{g} \mathrm{day}^{-1}\right)\end{array}$ \\
\hline
\end{tabular}




\begin{tabular}{|c|c|c|c|c|c|c|c|c|c|c|}
\hline \multirow{3}{*}{$\begin{array}{l}\text { Body and Hair } \\
\text { Wash }\end{array}$} & Shower gel & 2271.22 & 0.10 & --- & 2361.08 & 2038.24 & 241.26 & --- & na & 6911.89 \\
\hline & Shampoo & 124.75 & 13.09 & 11.65 & 4165.35 & 30572.42 & 12.08 & --- & na & 34899.33 \\
\hline & Hair conditioner & 6.36 & 0.44 & 0.29 & 106.25 & 845.94 & --- & 2.88 & na & 962.16 \\
\hline \multirow{2}{*}{ Toilet soaps } & Solid soap & 0.12 & 0.004 & --- & 0.57 & 15.06 & 0.01 & --- & na & 15.77 \\
\hline & Gel soap & 83.53 & 0.11 & 1.58 & 238.86 & 474.67 & 5.26 & 79.65 & na & 883.64 \\
\hline \multirow{2}{*}{ Shaving products } & Shaving foam/gel & 0.27 & 0.55 & --- & 15.04 & 209.05 & 21.87 & --- & na & 246.78 \\
\hline & Aftershave & 0.01 & --- & --- & 0.13 & 0.92 & 0.26 & --- & na & 1.32 \\
\hline Dentifrice products & Toothpaste & 0.11 & --- & --- & --- & 0.01 & --- & --- & na & 0.12 \\
\hline $\begin{array}{l}\text { Deodorants / } \\
\text { Antiperspirants }\end{array}$ & Roll-on deodorant & 0.08 & --- & 0.002 & 1.24 & 0.001 & 0.0004 & --- & na & 1.32 \\
\hline \multirow{3}{*}{ Moisturizers } & Hand cream & 0.05 & 0.01 & --- & 0.62 & 0.57 & --- & 0.30 & na & 1.54 \\
\hline & Facial cream & 0.03 & 0.0003 & 0.001 & 0.52 & 0.71 & 0.17 & --- & na & 1.43 \\
\hline & $\begin{array}{l}\text { Body } \\
\text { lotion/milk/cream }\end{array}$ & 3.61 & 0.23 & 0.002 & 228.35 & 49.68 & 1.66 & --- & na & 283.53 \\
\hline Perfumes & $\begin{array}{l}\text { Perfume/Eau de } \\
\text { toilette }\end{array}$ & 18.67 & 0.01 & 0.07 & 99.40 & 140.06 & 89.28 & --- & 110.19 & 457.68 \\
\hline TOTAL $\left(\mu \mathrm{g} \mathrm{day}^{-1}\right)$ & & 2508.80 & 14.55 & 13.59 & 7217.42 & 34347.31 & 371.84 & 82.83 & 110.19 & 44666.52 \\
\hline
\end{tabular}

